\title{
BARREMIAN AMMONOIDS FROM SAN LUCAS FORMATION AT HUETAMO REGION, MICHOACAN, MEXICO
}

GONZALEZ -ARREOLA, Celestina , Instituto de Geología UNAM, México D. F. 04510; *GARCIA-BARRERA, Pedro, Facultad de Ciencias UNAM México D. F. 04510; PANTOJA-ALOR J., Instituto de Geología UNAM México D. F. 04510; VILLASEÑOR, A. B., Instituto de Geología UNAM México D F. 04510.

We report here the species of ammonoids that actually have been found in two localities of Michoacán State, near San Lucas town; one of them is five kilometers north-west of it, and the other is six kilometers south-east of San Lucas. The former is called Arroyo Las Paredes section, and the second is called Tiringueo section.

Both localities are situated in the lower Member of San Lucas Formation (PantojaAlor, 1993) called Terrero Prieto; the upper Member is called Las Fraguas, characterized by volcaniclastic sediments.

The strata of San Lucas Formation were comformably deposited over the upper Jurassic sediments of The Angao Formation (Pantoja-Alor, 1959, 1993). San Lucas Formation represents a flysch sequence of shale, sandstone and conglomerate (turbidites), and was divided in two members: the lower Terrero Prieto Member consists of shale, calcareous sandstone and conglomerate, with some rudistid banks at the top of the section. Las Fraguas Member, almost 400 meters thick, consists of shale, feldespathic calcareous sandstone, siltstone and claystone, with predominance of volcaniclastic sediments that bear a variety of invertebrate marine fossils of Aptian age, including brachiopods, gastropods, echinoderms and very badly preserved ammonoids (Sour T. and García-Barrera, 1995).

The fossil assemblage of ammonoids is represented by two groups: the uncoiled forms : Leptoceras subtile Uhlig, Eoleptoceras sp. and Acrioceras (Acrioceras) cf. tabarelli (Astier), and the coiled ones: Pulchellia (Pulchellia) galeata (Von Buch) and Pulchellia (P) galeata cf. ornata Bürgl. The species cited above indicate a Barremian age for the strata that bear this fauna.

This work is a little part of a complete project that pretends to study the Cretaceous marine invertebrate fauna of the Huetamo region, so it represents preliminary results. 